\title{
ASUPAN GULA SEDERHANA DAN SERAT SERTA KADAR GLUKOSA DARAH PUASA (GDP) SEBAGAI FAKTOR RISIKO PENINGKATAN KADAR C-REACTIVE PROTEIN (CRP) PADA REMAJA OBESITAS DENGAN SINDROM METABOLIK
}

\author{
Atika Nurul Khiqmah, Muhammad Sulchan*) \\ Program Studi Ilmu Gizi Fakultas Kedokteran Universitas Diponegoro \\ Jl.Dr.Sutomo No.18, Semarang, Telp (024) 8453708, Email : gizifk@undip.ac.id
}

\begin{abstract}
Background : Prevalence of metabolic syndrome in adolescent increase with increasing prevalence of obesity. According to Riskedas 2013, the prevalence of obesity in adolescents age 16-18 increase from 1,4\% in 2010 to 1,6\% in 2013. Study in Semarang at 2005 show that 31,6\% obese adolescents meet the criteria of metabolic syndrome. Metabolic syndrome is the risk factor for cardiovascular diseases and diabetes mellitus type 2. The predictor for these risk factors is increasing $C$-reactive protein (CRP). This study aims to determine simple sugar, fiber intake and fasting blood glucose level as risk factors for increasing CRP in obesity adolescent with metabolic syndrome.

Methods : A cross-sectional study was conducted in SMA 2 Semarang. The subjects were selected based on inclusion criteria: age 15-18, obesity, and central obesity. Metabolic syndrome defined presence $\geq 3$ risk factors and pre metabolic syndrome presence $\leq 2$ risk factors: waist circumference $\geq 90^{\text {th }}$ percentile, sistolic and/or diastolic blood pressure $\geq 90^{\text {th }}$ percentile, fasting blood glucose level $\geq 110 \mathrm{mg} / \mathrm{dL}$, triglyceride $\geq 110 \mathrm{mg} / \mathrm{dL}$, or HDL $<40$ $m g / d L$. Simple sugar and fiber intake were obtained using Food Frequency Questionnaire (FFQ) method, fasting glucose level using enzymatic colorimetric method, and CRP using aglutination method. Correlation test used Pearson dan Spearman test. Ratio Prevalens (RP) values was used to calculate the risk of simple sugar, fiber intake and fasting blood glucose level for increasing $C R P$.

Results : The prevalence of metabolic syndrome in obesity adolescent was 15,2\%. Metabolic syndrome was found in boys only (21,27\%). High CRP was higher in girls (53,8\%) than boys. There were significant correlation between simple sugar $(p=0,024)$ and fiber $(p=0,034)$ intake with high CRP. The RP values for simple sugar, fiber intake and fasting blood glucose level were 2,1; 3,7; and 1,1 respectively.

Conclusion : High simple sugar, low fiber intake and fasting blood glucose level >81,5 mg/dL were risk factors for increasing CRP in adolescent obesity with metabolic syndrome, that risk factors respectively 2,1 times, 3,7 times, and 1,1 times.
\end{abstract}

Key words : simple sugar, fiber, fasting glucose level, C-reactive protein (CRP), obesity adolescent, metabolic syndrome

\begin{abstract}
ABSTRAK
Latar Belakang : Prevalensi sindrom metabolik pada remaja meningkat bersamaan dengan peningkatan prevalensi obesitas. Berdasarkan Riskesdas 2013, obesitas pada remaja usia 16-18 tahun meningkat dibandingkan tahun 2010, yaitu dari 1,4\% menjadi 1,6\%. Penelitian tahun 2005 di Semarang menunjukkan 31,6\% remaja obesitas memenuhi kriteria sindrom metabolik. Sindrom metabolik merupakan faktor risiko penyakit kardiovaskuler dan diabetes mellitus tipe 2. Prediktor untuk mengetahui risiko penyakit tersebut adalah peningkatan kadar C-reactive protein (CRP). Penelitian ini bertujuan untuk mengetahui asupan gula sederhana dan serat serta kadar Glukosa Darah Puasa (GDP) sebagai faktor risiko peningkatan CRP pada remaja obesitas dengan sindrom metabolik.

Metode : Penelitian dilakukan di SMA Negeri 2 Semarang dengan desain penelitian cross sectional. Subyek dipilih berdasarkan kriteria inklusi, yaitu berusia 15-18 tahun, obesitas dan obesitas sentral. Subyek dikatakan sindrom metabolik jika memenuhi $\geq 3$ faktor risiko dan pra sindrom jika memenuhi $\leq 2$ faktor risiko, yaitu lingkar pinggang $\geq$ persentil ke-90, tekanan darah sistolik dan/atau diastolik $\geq$ persentil ke-90, kadar GDP $\geq 110 \mathrm{mg} / \mathrm{dL}$, kadar trigliserida $\geq 110 \mathrm{mg} / \mathrm{dL}$, atau kadar $H D L<40 \mathrm{mg} / \mathrm{dL}$. Asupan gula sederhana dan serat menggunakan metode Food Frequency Questionnaire (FFQ), kadar GDP menggunakan metode enzymatic colorimetric, dan kadar CRP menggunakan metode aglutinasi. Uji hubungan menggunakan uji Pearson dan Spearman. Nilai Ratio Prevalens $(R P)$ untuk menghitung besar risiko asupan gula sederhana dan serat serta kadar GDP pada peningkatan kadar $C R P$.

Hasil : Prevalensi sindrom metabolik pada remaja obesitas sebesar 15,2\%. Sindrom metabolik hanya ditemukan pada subyek laki-laki (21,27\%). Frekuensi perempuan dengan kadar CRP tinggi lebih tinggi dibandingkan laki-laki $(53,8 \%)$.Terdapat hubungan bermakna asupan gula sederhana $(p=0,024)$ dan serat $(p=0,034)$ dengan kadar CRP tinggi. Nilai RP untuk asupan gula sederhana dan serat serta kadar GDP berturut-turut adalah 2,1; 3,7; dan 1,1.
\end{abstract}

\footnotetext{
${ }^{*}$ Penulis Penanggungjawab
} 
Simpulan : Asupan gula sederhana yang tinggi, asupan serat yang rendah, dan kadar GDP >81,5 mg/dL merupakan faktor risiko peningkatan kadar CRP pada remaja obesitas dengan sindrom metabolik, dengan besar risiko berturut-turut adalah 2,1 kali, 3,7 kali, dan 1,1 kali.

Kata Kunci : gula sederhana, serat, Glukosa Darah Puasa (GDP), C-reactive protein (CRP), remaja obesitas, sindrom metabolik

\section{PENDAHULUAN}

Sindrom metabolik merupakan masalah kesehatan yang prevalensinya semakin meningkat terutama pada remaja. Peningkatan prevalensi sindrom metabolik pada remaja bersamaan dengan peningkatan prevalensi obesitas sebagai salah satu faktor risiko sindrom metabolik. ${ }^{1}$ Berdasarkan Riset Kesehatan Dasar (Riskesdas) 2013, obesitas pada remaja usia 16-18 tahun meningkat dibandingkan tahun 2010, yaitu dari 1,4\% menjadi $1,6 \%{ }^{2,3}$ Penelitian tahun 2005 di Semarang menunjukkan $31,6 \%$ remaja obesitas memenuhi kriteria sindrom metabolik. ${ }^{4}$

Sindrom metabolik pada remaja berhubungan dengan obesitas. ${ }^{4}$ Peningkatan prevalensi obesitas pada remaja dapat dipengaruhi oleh perubahan gaya hidup yang berpengaruh pada kebiasaan makan. Remaja lebih sering makan di luar rumah dan mencoba makanan yang baru. ${ }^{5}$ Padahal, ketersediaan makanan yang ada cenderung merupakan unhealthy food, seperti fast food yang mengandung tinggi kalori, tinggi lemak, tinggi gula, tetapi rendah serat dimana merupakan faktor risiko obesitas. ${ }^{5}$ Peningkatan prevalensi obesitas pada remaja juga dipengaruhi oleh tingkat aktivitas fisik yang rendah. ${ }^{5}$ Jika tidak diatasi dengan baik, obesitas pada remaja berisiko tinggi menjadi obesitas di masa dewasa dan berpotensi mengalami penyakit kronis dan metabolik. ${ }^{6}$ Obesitas diketahui berhubungan dengan hipertensi, hiperglikemia, dan hipertrigliserida dimana ketiganya merupakan faktor risiko sindrom metabolik. $^{7}$

Sindrom metabolik merupakan faktor risiko terjadinya penyakit kardiovaskuler dan diabetes mellitus tipe $2 .{ }^{8}$ Prediktor yang dapat digunakan untuk mengetahui peningkatan risiko penyakit tersebut adalah tingginya kadar $C$-reactive protein (CRP). ${ }^{9}$ CRP merupakan prediktor yang kuat untuk penyakit kardiovaskuler dengan pengukuran yang sederhana, lebih murah, terstandar, dan tersedia secara luas. ${ }^{10}$ Kadar CRP yang tinggi dapat dipengaruhi oleh beberapa faktor, diantaranya adalah sindrom metabolik, faktor risiko sindrom metabolik, aktivitas fisik, dan asupan makanan.

Asupan makanan yang dapat mempengaruhi tingginya kadar CRP adalah asupan karbohidrat sederhana (gula sederhana) dan karbohidrat kompleks (serat). Beberapa penelitian menunjukkan adanya hubungan asupan gula sederhana dengan kadar CRP pada anak-anak, ${ }^{11}$ orang dewasa, ${ }^{12}$ subyek overweight,${ }^{13}$ dan subyek diabetes mellitus tipe $2 .{ }^{14}$ Asupan gula sederhana yang berlebihan dapat meningkatkan penyimpanannya dalam bentuk glikogen dan lemak sehingga menyebabkan overweight dan obesitas jika dikonsumsi terus menerus. Adanya penumpukan lemak dapat memicu inflamasi yang mengakibatkan tingginya kadar CRP. ${ }^{15}$ Namun, Souto et al menyebutkan bahwa jumlah asupan gula sederhana tidak berhubungan dengan kadar CRP pada subyek diabetes mellitus tipe $1 .{ }^{16}$

Asupan karbohidrat kompleks yang berhubungan dengan tingginya kadar CRP adalah rendahnya asupan serat. Asupan serat yang rendah berhubungan dengan hiperglikemia dimana dapat meningkatkan proinflamatori sitokin interleukin 6 (IL-6), tumor necrosis factor $\alpha$ (TNF- $\alpha$ ), dan interleukin 18 (IL-18). ${ }^{17}$ Peningkatan IL-6 secara konsisten dapat menyebabkan peningkatan kadar CRP. Yunsheng et al menyebutkan bahwa asupan serat yang tinggi merupakan faktor protektif untuk melawan peningkatan kadar CRP. ${ }^{18}$ Selain dari asupan makanan, salah satu faktor risiko sindrom metabolik yang berhubungan dengan tingginya kadar CRP adalah kadar Glukosa Darah Puasa (GDP).

Abrado et al menyebutkan bahwa kadar GDP yang tinggi atau hiperglikemia berhubungan dengan kadar CRP yang tinggi. ${ }^{19}$ Hal ini berkaitan dengan kadar CRP sebagai salah satu biomarker inflamasi yang berhubungan dengan perubahan metabolisme glukosa. ${ }^{20}$ Hiperglikemia dapat memicu terjadinya Advanced Glycation-End Products yang menstimulasi hati untuk meningkatkan CRP. ${ }^{21}$ Hiperglikemia juga dapat menstimulasi pelepasan inflamasi sitokin IL-6 dan TNF- $\alpha .{ }^{16}$ Namun, Kawamoto et al menyebutkan bahwa hiperglikemia memiliki hubungan yang kuat dengan kadar CRP tinggi hanya pada subyek perempuan yang mengalami obesitas. ${ }^{22}$

Penelitian mengenai asupan gula sederhana dan serat serta kadar GDP sebagai faktor risiko peningkatan kadar CRP pada remaja obesitas dengan sindrom metabolik di Indonesia masih terbatas. Berdasarkan uraian di atas, peneliti 
tertarik untuk mengetahui asupan gula sederhana dan serat serta kadar GDP sebagai faktor risiko peningkatan kadar CRP pada remaja obesitas dengan sindrom metabolik.

\section{METODE PENELITIAN}

Penelitian ini termasuk dalam ruang lingkup keilmuan gizi masyarakat dengan desain penelitian cross-sectional. Pengambilan data terdiri dari 2 tahap, yaitu pengambilan data awal (skrining) dan pengambilan data lanjut yang dilakukan pada bulan Mei 2014.

Populasi pada penelitian ini adalah semua siswa usia 15-18 tahun di SMA Negeri 2 Semarang. Subyek dipilih berdasarkan kriteria inklusi, yaitu berusia 15-18 tahun, obesitas (BMIfor age percentile $\geq$ persentil ke-95), dan obesitas sentral (lingkar pinggang $\geq$ persentil ke-90). Kriteria eksklusi adalah subyek mengundurkan diri, sakit, atau meninggal dunia saat penelitian berlangsung.

Pada penelitian ini dilakukan pengukuran antropometri, tekanan darah, dan pemeriksaan sampel darah. Pengukuran antropometri meliputi berat badan, tinggi badan, dan lingkar pinggang. Berat badan diukur menggunakan timbangan digital dengan ketelitian $0,01 \mathrm{~kg}$, tinggi badan menggunakan microtoise dengan ketelitian $0,1 \mathrm{~cm}$, dan lingkar pinggang menggunakan pita meter dengan ukuran maksimal $150 \mathrm{~cm}$. Tekanan darah diukur menggunakan indirect method dengan cara auskultasi. Pemeriksaan sampel darah dilakukan di Laboratorium Klinik Semarang.

Subyek termasuk sindrom metabolik jika memenuhi $\geq 3$ faktor risiko dan pra sindrom metabolik (sindrom metabolik ringan) jika memenuhi $\leq 2$ faktor risiko berdasarkan National Cholesterol Education Program Adult Treatment Panel III (NCEP ATP III) untuk remaja, yaitu lingkar pinggang $\geq$ persentil ke-90 $(\geq 93 \mathrm{~cm}$ untuk laki-laki dan $\geq 87 \mathrm{~cm}$ untuk perempuan), tekanan darah sistolik dan/atau diastolik $\geq$ persentil ke-90 (tekanan darah sistolik $\geq 122 \mathrm{mmHg}$ dan/atau diastolik $\geq 77 \mathrm{mmHg}$ ), kadar GDP $\geq 110 \mathrm{mg} / \mathrm{dL}$, kadar trigliserida $\geq 110 \mathrm{mg} / \mathrm{dL}$, dan kadar kolesterol HDL $<40 \mathrm{mg} / \mathrm{dL}^{23}$

Besar sampel dihitung menggunakan rumus dan didapatkan sampel minimal sebanyak 38 sampel. Besar sampel yang digunakan untuk melihat prevalensi faktor risiko sindrom metabolik sesuai dengan jumlah subyek yang didapat dari hasil skrining, yaitu 47 subyek, sedangkan untuk pemeriksaan kadar $C$-reactive protein (CRP) serta asupan gula sederhana dan serat sebanyak 38 subyek. Setiap subyek terpilih diberikan informed consent sebagai tanda persetujuan menjadi subyek penelitian. Pembuatan ethical clearance diajukan kepada Komite Etik Penelitian Fakultas Kedokteran Universitas Diponegoro/RSUP Dr Kariadi Semarang. Variabel terikat pada penelitian ini adalah kadar CRP, sedangkan variabel bebas adalah asupan gula sederhana, asupan serat, dan kadar GDP.

Kadar CRP merupakan sebuah parameter yang mengambarkan adanya inflamasi serta prediktor peningkatan risiko penyakit kardiovaskuler dan diabetes mellitus tipe 2. Kadar CRP diukur menggunakan metode aglutinasi. Kadar CRP dikatakan tinggi apabila $>6 \mathrm{mg} / \mathrm{L}$ dan normal apabila $<6 \mathrm{mg} / \mathrm{L}$.

Asupan gula sederhana merupakan rata-rata asupan monosakarida, disakarida, dan oligosakarida dari makanan maupun minuman dimana dikatakan tinggi apabila $>10 \%$ total kebutuhan energi, ${ }^{24}$ yaitu $>66,875$ gram untuk lakilaki dan $>53,125$ gram untuk perempuan berdasarkan Angka Kecukupan Gizi (AKG) 2013. Asupan serat merupakan rata-rata asupan serat dari makanan maupun minuman dimana dikatakan rendah apabila <37 gram untuk laki-laki dan $<30$ gram untuk perempuan berdasarkan AKG 2013. Data asupan gula sederhana dan serat diperoleh menggunakan metode Food Frequency Questionnaire (FFQ) semi kuantitatif yang kemudian dikonversikan ke dalam satuan gram/hari.

Kadar Glukosa Darah Puasa (GDP) merupakan sebuah parameter yang menggambarkan konsentrasi glukosa di dalam plasma darah yang diukur pada subyek yang berpuasa selama 8-12 jam. ${ }^{4}$ Kadar GDP diukur dengan menggunakan metode enzymatic colorimetric. Kadar GDP dikatakan tinggi apabila $\geq 110 \mathrm{mg} / \mathrm{dL}^{23}$ Kadar GDP pada penelitian ini dikategorikan berdasarkan nilai median menjadi $>81,5 \mathrm{mg} / \mathrm{dL}$ dan $<81,5 \mathrm{mg} / \mathrm{dL}$ untuk melihat perbedaan kadar GDP pada kelompok kadar CRP tinggi dan kelompok kadar CRP normal karena semua subyek memiliki kadar GDP yang normal.

Pengolahan dan analisis data menggunakan program komputer. Analisis deskriptif digunakan untuk melihat gambaran karakteristik subyek penelitian. Uji hubungan Pearson dan Spearman dilakukan untuk menguji hubungan asupan gula sederhana dan serat dengan faktor risiko sindrom metabolik serta hubungan asupan gula sederhana dan serat serta kadar GDP dengan kadar CRP tinggi, yang sebelumnya dilakukan uji normalitas 
data menggunakan uji Shapiro-Wilk. Besarnya risiko asupan gula sederhana dan serat serta kadar GDP pada peningkatan kadar CRP diketahui dengan menghitung nilai Ratio Prevalens (RP).

\section{HASIL PENELITIAN Karakteristik Subyek Penelitian}

Hasil skrining awal yang melibatkan 835 remaja SMA Negeri 2 Semarang menunjukkan terdapat $80(9,58 \%)$ remaja overweight, $66(7,9 \%)$ remaja obesitas, $61(7,3 \%)$ remaja obesitas sentral, dan $10(1,2 \%)$ remaja sindrom metabolik. Jika dilihat diantara remaja obesitas, terdapat $15,2 \%$ remaja sindrom metabolik. Karakteristik subyek penelitian dapat dilihat pada tabel 1,2, dan 3 .

Tabel 1. Usia, Status Gizi, dan Faktor Risiko Sindrom Metabolik

\begin{tabular}{|c|c|c|}
\hline Variabel & Sindrom Metabolik & $\begin{array}{c}\text { Pra Sindrom } \\
\text { Metabolik }\end{array}$ \\
\hline Total & $(n=10)$ & $(n=37)$ \\
\hline Usia (th) & $16,5(15-17)^{*}$ & $16(15-17)^{*}$ \\
\hline $\operatorname{IMT}\left(\mathrm{Kg} / \mathrm{m}^{2}\right)$ & $32,5(29,6-45,6)^{*}$ & $30,3(25,9-43,3) *$ \\
\hline Lingkar Pinggang $(\mathrm{cm})$ & $105(97,5-120,3)^{*}$ & $93,5(87-134)^{*}$ \\
\hline TD Sistolik (mmHg) & $130(120-140)^{*}$ & $110(100-140)^{*}$ \\
\hline TD Diastolik (mmHg) & $70(70-80)^{*}$ & $70(70-80)^{*}$ \\
\hline GDP $(\mathrm{mg} / \mathrm{dL})$ & $79,9 \pm 10,9 * *$ & $82,2 \pm 6,2 * *$ \\
\hline Trigliserida $(\mathrm{mg} / \mathrm{dL})$ & $119(72-181)^{*}$ & $72(50-135)^{*}$ \\
\hline Kolesterol HDL (mg/dL) & $32,5(30-48)^{*}$ & $42(30-56)^{*}$ \\
\hline Laki-laki & $(\mathbf{n}=\mathbf{1 0})$ & $(n=18)$ \\
\hline Usia (th) & $16,5(15-17)^{*}$ & $16(15-17)^{*}$ \\
\hline $\operatorname{IMT}\left(\mathrm{Kg} / \mathrm{m}^{2}\right)$ & $32,6(29,6-45,6)^{*}$ & $30,3(25,9-43,3) *$ \\
\hline Lingkar Pinggang (cm) & $105,9 \pm 8,1 * *$ & $101,4 \pm 10,3^{* *}$ \\
\hline TD Sistolik (mmHg) & $130(120-140)^{*}$ & $120(110-140)^{*}$ \\
\hline TD Diastolik (mmHg) & $70(70-80)^{*}$ & $70(70-80)^{*}$ \\
\hline GDP $(\mathrm{mg} / \mathrm{dL})$ & $79,9 \pm 10,9 * *$ & $83,6 \pm 5,6^{* *}$ \\
\hline Trigliserida $(\mathrm{mg} / \mathrm{dL})$ & $117,2 \pm 32,5 * *$ & $76,5 \pm 15,2 * *$ \\
\hline Kolesterol HDL (mg/dL) & $32,5(30-48)^{*}$ & $40(30-56)^{*}$ \\
\hline Perempuan & & $(n=19)$ \\
\hline Usia (th) & - & $16(15-17)^{*}$ \\
\hline $\operatorname{IMT}\left(\mathrm{Kg} / \mathrm{m}^{2}\right)$ & - & $31,4 \pm 2,8 * *$ \\
\hline Lingkar Pinggang $(\mathrm{cm})$ & - & $90(87-114,4)^{*}$ \\
\hline TD Sistolik (mmHg) & - & $110(100-120)^{*}$ \\
\hline TD Diastolik (mmHg) & - & $70(70-70)^{*}$ \\
\hline GDP $(\mathrm{mg} / \mathrm{dL})$ & - & $81 \pm 6,6^{* *}$ \\
\hline Trigliserida (mg/dL ) & - & $51(50-135)^{*}$ \\
\hline Kolesterol HDL (mg/dL) & - & $44,1 \pm 6,1 * *$ \\
\hline
\end{tabular}

Tabel 1 menunjukkan kelompok sindrom metabolik memiliki nilai median dan mean yang lebih tinggi, kecuali variabel tekanan darah diastolik, Glukosa Darah Puasa (GDP), memiliki nilai median yang sama pada kedua kelompok, sedangkan nilai median kolesterol HDL dan nilai mean GDP pada kelompok sindrom metabolik lebih rendah. dan kolesterol HDL. Tekanan darah diastolik

Tabel 2. Frekuensi Faktor Risiko Sindrom Metabolik

\begin{tabular}{lcccc}
\hline \multicolumn{1}{c}{ Faktor Risiko } & \multicolumn{2}{c}{$\begin{array}{c}\text { Sindrom } \\
\text { Metabolik }(\mathbf{n = 1 0})\end{array}$} & \multicolumn{2}{c}{$\begin{array}{c}\text { Pra Sindrom } \\
\text { Metabolik }(\mathbf{n = 3 7})\end{array}$} \\
\hline Total & & & & \\
Lingkar Pinggang $\geq$ persentil ke-90 & 10 & $100 \%$ & 37 & $100 \%$ \\
TD Sistolik $\geq 122 \mathrm{mmHg}$ & 8 & $80 \%$ & 2 & $5,4 \%$ \\
TD Diastolik $\geq 77 \mathrm{mmHg}$ & 4 & $40 \%$ & 1 & $2,7 \%$ \\
GDP $\geq 110 \mathrm{mg} / \mathrm{dL}$ & - & - & - & - \\
Trigliserida $\geq 110 \mathrm{mg} / \mathrm{dL}$ & 6 & $60 \%$ & 3 & $8,1 \%$ \\
Kolesterol HDL $<40 \mathrm{mg} / \mathrm{dL}$ & 9 & $90 \%$ & 13 & $35,1 \%$
\end{tabular}




\begin{tabular}{lcccc} 
Laki-laki & & & \\
Lingkar Pinggang $\geq 93 \mathrm{~cm}$ & 10 & $100 \%$ & 18 & $100 \%$ \\
TDS $\geq 122 \mathrm{mmHg}$ & 8 & $80 \%$ & 2 & $11,1 \%$ \\
$\mathrm{TDD} \geq 77 \mathrm{mmHg}$ & 4 & $40 \%$ & 1 & $5,6 \%$ \\
GDP $\geq 100 \mathrm{mg} / \mathrm{dL}$ & - & - & - & - \\
Trigliserida $\geq 110 \mathrm{mg} / \mathrm{dL}$ & 6 & $60 \%$ & - & - \\
HDL $<40 \mathrm{mg} / \mathrm{dL}$ & 9 & $90 \%$ & 9 & $50 \%$ \\
Perempuan & & & & \\
Lingkar Pinggang $\geq 87 \mathrm{~cm}$ & - & - & 19 & $100 \%$ \\
TD Sistolik $\geq 122 \mathrm{mmHg}$ & - & - & - & - \\
TD Diastolik $\geq 77 \mathrm{mmHg}$ & - & - & - & - \\
GDP $\geq 110 \mathrm{mg} / \mathrm{dL}$ & - & - & - & - \\
Trigliserida $\geq 110 \mathrm{mg} / \mathrm{dL}$ & - & - & 3 & $15,8 \%$ \\
Kolesterol HDL $<40 \mathrm{mg} / \mathrm{dL}$ & - & - & 4 & $21,1 \%$ \\
\hline
\end{tabular}

Tabel 2 menunjukkan obesitas sentral berdasarkan lingkar pinggang $\geq$ persentil ke-90 memiliki frekuensi tertinggi $(100 \%)$ pada kedua kelompok karena merupakan faktor skrining dalam penelitian. Urutan frekuensi faktor risiko sindrom metabolik berturut-turut dari yang tertinggi adalah lingkar pinggang $\geq$ persentil ke-90, kolesterol HDL $<40 \mathrm{mg} / \mathrm{dL}$, tekanan darah sistolik $\geq 122 \mathrm{mmHg}$, dan trigliserida $\geq 110 \mathrm{mg} / \mathrm{dL}$. Faktor risiko Glukosa Darah Puasa $(\mathrm{GDP}) \geq 110 \mathrm{mg} / \mathrm{dL}$ tidak terpenuhi pada kedua kelompok karena semua subyek memiliki kadar GDP normal.

Tabel 3. Kadar CRP berdasarkan Jenis Kelamin Subyek

\begin{tabular}{lccccc}
\hline \multirow{2}{*}{ Jenis Kelamin } & \multicolumn{2}{c}{ Kadar CRP } & \multicolumn{2}{c}{ Kadar CRP } \\
Ninggi $(\mathbf{n = 1 3})$ & Normal $(\mathbf{n = 2 5})$ & Total \\
& 6 & $46,2 \%$ & 18 & $72 \%$ & 24 \\
\hline Laki-laki & 7 & $53,8 \%$ & 7 & $38 \%$ & 14 \\
Perempuan & 13 & $100 \%$ & 25 & $100 \%$ & 38 \\
Total & & & & & \\
\hline
\end{tabular}

Tabel 3 menunjukkan frekuensi perempuan frekuensi laki-laki dengan kadar CRP normal lebih dengan kadar CRP tinggi lebih tinggi tinggi dibandingkan dengan perempuan.

dibandingkan dengan laki-laki, sedangkan Hubungan Asupan Gula Sederhana dan Serat dengan Faktor Risiko Sindrom Metabolik

Tabel 4. Hubungan Asupan Gula Sederhana dan Serat dengan Faktor Risiko Sindrom Metabolik

\begin{tabular}{lcccc}
\hline \multirow{2}{*}{ Variabel } & \multicolumn{2}{c}{ Asupan Gula } & \multicolumn{2}{c}{ Asupan Serat } \\
\cline { 2 - 5 } & $\mathbf{r}$ & $\boldsymbol{p}$ & $\mathbf{r}$ & $\boldsymbol{p}$ \\
\hline IMT (kg/m ${ }^{2}$ ) & 0,170 & 0,306 & $-0,147$ & 0,378 \\
Lingkar Pinggang (cm) & 0,115 & 0,490 & $-0,298$ & 0,070 \\
TD Sistolik (mmHg) & 0,265 & 0,107 & $-0,293$ & 0,074 \\
TD Diastolik (mmHg) & 0,012 & 0,942 & $-0,036$ & 0,832 \\
GDP (mg/dL) & $-0,132$ & 0,431 & 0,101 & 0,547 \\
Trigliserida (mg/dL) & 0,335 & $0,040^{*}$ & $-0,354$ & $0,029^{*}$ \\
Kolesterol HDL (mg/dL) & $-0,088$ & 0,600 & 0,130 & 0,436 \\
\hline
\end{tabular}

Keterangan: * $\mathrm{p}<0,05$

Tabel 4 menunjukkan hubungan yang bermakna antara asupan gula sederhana $(\mathrm{p}=0,040)$ dan asupan serat $(\mathrm{p}=0,029)$ dengan kadar trigliserida.
Hubungan Asupan Gula Sederhana dan Serat serta Kadar Glukosa Darah Puasa (GDP) dengan Kadar $C$-reactive protein (CRP) Tinggi

Tabel 5. Hubungan Asupan Gula Sederhana dan Serat serta Kadar GDP dengan Kadar CRP Tinggi

\begin{tabular}{lcc}
\multicolumn{1}{c}{ Variabel } & \multicolumn{2}{c}{ Kadar CRP Tinggi } \\
\cline { 2 - 3 } & $\mathbf{r}$ & $\boldsymbol{p}$ \\
\hline Asupan Gula Sederhana (g/hari) & 0,366 & $0,024^{*}$ \\
Asupan Serat (g/hari) & $-0,345$ & $0,034^{*}$ \\
GDP (mg/dL) & 0,044 & 0,795 \\
\hline
\end{tabular}

Keterangan: $* \mathrm{p}<0,05$ 
Tabel 5 menunjukkan hubungan bermakna antara asupan gula sederhana $(\mathrm{p}=0,024)$ dan asupan serat $(\mathrm{p}=0,034)$ dengan kadar CRP tinggi, sedangkan kadar GDP ( $\mathrm{p}=0,795)$ tidak memiliki hubungan bermakna dengan kadar CRP tinggi.

Asupan Gula Sederhana, Asupan Serat, dan Kadar Glukosa Darah Puasa (GDP) sebagai Faktor Risiko Peningkatan Kadar $C$-reactive protein (CRP)
Tabel 6 menunjukkan lebih dari 75\% remaja dengan kadar CRP tinggi mengkonsumsi gula sederhana $>10 \%$ total kebutuhan energi. Saat penelitian dilakukan, gula sederhana yang paling banyak dikonsumsi oleh remaja adalah minuman manis dan soft drink. Nilai Ratio Prevalens (RP) asupan gula sederhana tinggi sebesar 2,174 menunjukkan bahwa remaja dengan asupan gula sederhana yang tinggi berisiko 2,1 kali untuk memiliki kadar CRP tinggi.

Tabel 6. Asupan Gula Sederhana, Asupan Serat, dan Kadar GDP sebagai Faktor Risiko Peningkatan

\begin{tabular}{|c|c|c|c|c|c|}
\hline & \multicolumn{4}{|c|}{ Kadar CRP } & \multirow{3}{*}{$\mathbf{R P}$} \\
\hline & \multicolumn{2}{|c|}{$\begin{array}{c}\text { Kadar CRP } \\
\text { Tinggi }\end{array}$} & \multicolumn{2}{|c|}{$\begin{array}{c}\text { Kadar CRP } \\
\text { Normal }\end{array}$} & \\
\hline & $\mathrm{N}$ & $\%$ & $\mathrm{~N}$ & $\%$ & \\
\hline \multicolumn{6}{|l|}{ Asupan Gula Sederhana } \\
\hline Tinggi & 10 & 76,9 & 13 & 52 & 2,174 \\
\hline Normal & 3 & 23,1 & 12 & 48 & \\
\hline \multicolumn{6}{|l|}{ Asupan Serat } \\
\hline Rendah & 12 & 92,3 & 17 & 68 & 3,724 \\
\hline Normal & 1 & 7,7 & 8 & 32 & \\
\hline \multicolumn{6}{|l|}{ Kadar GDP } \\
\hline$>81,5 \mathrm{mg} / \mathrm{dL}$ & 7 & 53,8 & 12 & 48 & 1,167 \\
\hline$<81,5 \mathrm{mg} / \mathrm{dL}$ & 6 & 46,2 & 13 & 52 & \\
\hline
\end{tabular}

Lebih dari 90\% remaja dengan kadar CRP tinggi mengkonsumsi serat kurang dari kebutuhan. Saat penelitian dilakukan, sebagian besar remaja jarang mengkonsumsi sayur dan buah. Nilai RP untuk asupan serat rendah sebesar 3,724 menunjukkan bahwa remaja dengan asupan serat yang rendah berisiko 3,7 kali untuk memiliki kadar CRP tinggi.

Lebih dari $50 \%$ remaja dengan kadar CRP tinggi memiliki kadar GDP $>81,5 \mathrm{mg} / \mathrm{dL}$. Nilai RP kadar GDP >81,5 mg/dL sebesar 1,167 menunjukkan bahwa remaja dengan kadar GDP $>81,5 \mathrm{mg} / \mathrm{dL}$ berisiko 1,1 kali untuk memiliki kadar CRP tinggi.

\section{PEMBAHASAN}

Penelitian pendahuluan terhadap 835 remaja SMA Negeri 2 Semarang menunjukkan prevalensi sindrom metabolik pada remaja obesitas sebesar $15,2 \%$. Prevalensi ini lebih tinggi dibandingkan prevalensi sindrom metabolik pada remaja obesitas tahun 2011 di Tomohon, yaitu 5\%. ${ }^{25}$ Namun, lebih rendah dibandingkan prevalensi sindrom metabolik pada remaja obesitas tahun 2005 di Semarang, yaitu 31,6\%. ${ }^{4} \mathrm{Hal}$ ini dapat dipengaruhi oleh karakteristik subyek. Penelitian tahun 2005 di Semarang dilakukan di sekolah swasta yang mayoritas adalah remaja Cina dengan tingkat sosial ekonomi menengah ke atas sehingga dapat mempengaruhi gaya hidup, terutama pada kebiasaan makan dan aktivitas fisik subyek yang berbeda dengan remaja pada penelitian ini.

Hasil penelitian menunjukkan bahwa prevalensi sindrom metabolik hanya ditemukan pada subyek laki-laki. Hasil ini sejalan dengan penelitian tahun 2006 di Jakarta Utara dan Selatan yang menyebutkan prevalensi sindrom metabolik pada remaja obesitas laki-laki lebih tinggi dibandingkan dengan perempuan. ${ }^{26}$ Penelitian tahun 2013 di Iran juga menyebutkan bahwa prevalensi sindrom metabolik pada remaja lakilaki lebih tinggi dibandingkan dengan perempuan. $^{27}$ Hal ini dapat dipengaruhi oleh penurunan testosteron yang terjadi pada laki-laki obesitas akibat konversi testosteron menjadi estrogen dalam jaringan lemak perifer yang berlebihan. Penurunan testosteron dapat meningkatkan aktivitas lipoprotein lipase, uptake trigliserida, massa lemak, dan LDL yang bermuara pada sindrom metabolik. ${ }^{28}$ Selain itu, tidak ditemukannya sindrom metabolik pada remaja perempuan dapat dipengaruhi oleh usia. Prevalensi sindrom metabolik pada perempuan meningkat sesuai dengan perkembangan usia, yaitu pada usia lebih dari 50 tahun, yang berhubungan dengan keadaan menopouse. ${ }^{29}$

Urutan faktor risiko sindrom metabolik yang terpenuhi berdasarkan kriteria NCEP ATP III 
untuk remaja pada penelitian ini berturut-turut dari yang tertinggi adalah obesitas sentral, hipokolesterol HDL (High Density Lipoprotein), hipertensi, dan hipertrigliserida. Hasil ini sejalan dengan penelitian tahun 2013 di Brazil yang menyebutkan bahwa urutan faktor risiko sindrom metabolik pada remaja adalah obesitas sentral (55\%), hipokolesterol HDL (35,5\%), hipertensi $(21 \%)$, hipertrigliserida $(18,5 \%)$, dan hiperglikemia $(2 \%){ }^{29}$ Tidak terpenuhinya hiperglikemia sebagai faktor risiko sindrom metabolik pada hasil penelitian ini dapat didukung dengan hasil penelitian di Brazil yang menyebutkan bahwa hiperglikemia pada remaja memiliki persentase terkecil, yaitu $2 \%$. Hal ini menunjukkan bahwa hiperglikemia merupakan faktor risiko yang muncul paling akhir diantara faktor risiko sindrom metabolik lainnya pada remaja. ${ }^{30}$ Kadar Glukosa Darah Puasa (GDP) normal yang ditemukan pada semua remaja menunjukkan bahwa metabolisme karbohidrat masih berjalan dengan baik dimana tubuh dapat mempertahankan kadar glukosa darah normal melalui hormon insulin yang disekresikan pankreas. $^{31}$

Obesitas sentral merupakan faktor risiko sindrom metabolik dengan persentase tertinggi diantara faktor risiko lainnya sehingga dapat disebut sebagai faktor risiko utama sindrom metabolik. ${ }^{15}$ Obesitas sentral pada remaja dapat dipengaruhi oleh asupan makanan, seperti asupan gula sederhana yang tinggi dan asupan serat yang rendah. Namun, hasil penelitian menunjukkan bahwa diantara kelima faktor risiko sindrom metabolik, asupan gula sederhana pada remaja obesitas memiliki hubungan bermakna dengan kadar trigliserida $(p=0,040)$, bukan dengan obesitas sentral. Asupan gula sederhana yang tinggi dapat meningkatkan pelepasan insulin. Meningkatnya insulin yang dilepaskan mengakibatkan efek dari insulin yang berfungsi untuk menjaga kadar glukosa darah normal masih tetap berlangsung meskipun absorpsi makanan telah selesai, yaitu pada 2 jam setelah makan. Hal ini dapat mengakibatkan kadar glukosa darah berada di bawah normal sehingga tubuh menginterpretasikan sebagai keadaan hipoglikemia dan melepaskan asam lemak bebas dari sel-sel lemak. Setelah itu, asam lemak menuju transport Very Low-Density Lipoprotein (VLDL) di hati dan mengakibatkan peningkatan serum trigliserida. ${ }^{32}$ Selain asupan gula sederhana, asupan serat juga memiliki hubungan dengan trigliserida.
Hasil penelitian menunjukkan bahwa diantara faktor risiko sindrom metabolik yang lain, asupan serat pada remaja obesitas memiliki hubungan bermakna dengan kadar trigliserida $(p=0,029)$. Hasil ini sejalan dengan penelitian Anderson yang menyebutkan bahwa asupan serat yang rendah dapat meningkatkan kadar trigliserida. ${ }^{33}$ Asupan serat yang tinggi dapat meningkatkan ekskresi asam empedu dan kolesterol melalui feses sehingga mengurangi asam empedu untuk masuk kembali ke hati. Berkurangnya asam empedu ke hati menyebabkan peningkatan penggunaan kolesterol menjadi asam empedu baru sehingga berefek pada penurunan kadar kolesterol dan trigliserida. ${ }^{34}$ Selain kadar trigliserida, asupan gula sederhana dan serat juga berhubungan dengan kadar $C$-reactive protein (CRP) tinggi.

Kadar CRP tinggi merupakan salah satu prediktor adanya peningkatan risiko berkembangnya sindrom metabolik menjadi penyakit kardiovaskuler dan diabetes mellitus tipe 2. Hasil penelitian menunjukkan bahwa frekuensi remaja perempuan dengan kadar CRP tinggi lebih tinggi dibandingkan dengan laki-laki. Hasil ini sejalan dengan penelitian tahun 2013 di Brazil yang menunjukkan bahwa remaja perempuan memiliki kadar CRP yang lebih tinggi dibandingkan dengan laki-laki. ${ }^{35}$ Hal ini dapat dipengaruhi oleh persen lemak tubuh dan jaringan adiposa yang lebih besar pada perempuan dibandingkan dengan laki-laki. ${ }^{35}$ Jaringan adiposa yang besar dapat mensekresikan proinflamasi sitokin, seperti interleukin 6 (IL-6) dan tumor necrosis factor $\alpha$ (TNF- $\alpha$ ) yang menstimulasi hati untuk memproduksi CRP. ${ }^{36}$

Hasil penelitian menunjukkan bahwa asupan gula sederhana memiliki hubungan bermakna dengan kadar CRP tinggi $(\mathrm{p}=0,024)$. Nilai RP asupan gula sederhana terhadap kadar CRP sebesar 2,174 menunjukkan bahwa remaja obesitas dengan asupan gula sederhana yang tinggi berisiko 2,1 kali untuk memiliki kadar CRP tinggi. Lebih dari $75 \%$ remaja dengan kadar CRP tinggi mengkonsumsi gula sederhana $>10 \%$ total kebutuhan energi. Sebagian besar remaja mengkonsumsi gula sederhana dalam bentuk minuman manis. Hasil ini sejalan dengan penelitian Kosova et al yang menyebutkan bahwa tingginya asupan minuman manis berhubungan dengan peningkatan kadar CRP. ${ }^{11}$ Gula sederhana mengandung tinggi energi yang mudah diserap oleh usus untuk digunakan sebagai energi serta diubah menjadi glikogen dan lemak yang disimpan di hati dan jaringan lemak. 
Konsumsi karbohidrat dalam bentuk minuman manis tidak menimbulkan rasa puas seperti karbohidrat lain yang mengandung tinggi energi sehingga meningkatkan frekuensi konsumsinya. ${ }^{37}$ Jika dikonsumsi terus menerus, asupan minuman manis dapat menimbulkan obesitas. Timbunan lemak yang dihasilkan terutama lemak abdominal dapat menyebabkan peningkatan pelepasan IL-6, bahan dasar untuk merangsang pembentukan CRP. ${ }^{15}$ Selain itu, tingginya kecepatan penyerapan gula pada minuman manis dapat menyebabkan peningkatan glycemic load dimana berhubungan dengan inflamasi dan peningkatan risiko penyakit kardiovaskuler. $^{38}$

Hasil penelitian menunjukkan bahwa asupan serat memiliki hubungan bermakna dengan kadar CRP tinggi $(\mathrm{p}=0,034)$. Nilai $\mathrm{RP}$ asupan serat terhadap kadar CRP sebesar 3,724 menunjukkan bahwa remaja obesitas dengan asupan serat yang rendah dapat berisiko 3,7 kali untuk memiliki kadar CRP tinggi. Lebih dari $90 \%$ remaja dengan kadar CRP tinggi mengkonsumsi serat kurang dari kebutuhan. Hampir semua remaja jarang mengkonsumsi sayur dan buah. Penelitian Yunsheng et al menyebutkan bahwa asupan serat yang tinggi merupakan faktor protektif untuk melawan peningkatan kadar CRP. ${ }^{18}$ Asupan serat yang tinggi dapat menurunkan oksidasi lemak sehingga terjadi penurunan inflamasi. ${ }^{39}$ Efek antiinflamasi pada asupan serat yang tinggi berhubungan dengan kemampuannya dalam menurunkan substansi-substansi yang mengakibatkan inflamasi, yaitu mencegah terjadinya hiperglikemia dan efeknya pada lemak terutama pada kolesterol LDL (Low Density Lipoprotein).$^{18}$ Selain dari asupan makanan, kadar CRP tinggi dapat dipengaruhi oleh salah satu faktor risiko sindrom metabolik, yaitu kadar GDP yang tinggi atau hiperglikemia.

Hiperglikemia dapat memicu terjadinya Advanced Glycation-End Products yang menstimulasi hati untuk meningkatkan produksi protein fase akut, yaitu $\mathrm{CRP}^{21}$ Selain itu, hiperglikemia juga dapat menstimulasi pelepasan proinflamasi sitokin IL-6 dan TNF- $\alpha .{ }^{15}$ Namun, semua subyek penelitian ini memiliki kadar GDP normal, yaitu $\leq 110 \mathrm{mg} / \mathrm{dL}$. Hal ini dapat dipengaruhi oleh karakteristik subyek yang merupakan remaja usia 16-18 tahun. Metabolisme karbohidrat pada usia remaja masih berjalan dengan baik dimana tubuh dapat mempertahankan kadar glukosa darah normal melalui hormon insulin yang disekresikan pankreas. ${ }^{31}$ Selain itu, kadar GDP yang tinggi merupakan faktor risiko sindrom metabolik yang muncul paling akhir dibandingkan dengan faktor risiko lainnya pada remaja obesitas. Penelitian di Brazil yang menunjukkan bahwa hiperglikemia pada remaja memiliki prevalensi paling rendah dibandingkan faktor risiko sindrom metabolik lainnya, yaitu $2 \% .^{30}$

Hasil penelitian menunjukkan bahwa kadar GDP tidak memiliki hubungan bermakna dengan kadar CRP tinggi $(p=0,795)$. Hal ini dapat dipengaruhi oleh jumlah remaja dengan kadar CRP tinggi yang sedikit serta kadar GDP yang normal pada semua remaja. Untuk melihat besar risiko terhadap peningkatan kadar CRP, maka dilakukan pengkategorian kadar GDP normal menjadi $>81,5$ $\mathrm{mg} / \mathrm{dL}$ dan $<81,5 \mathrm{mg} / \mathrm{dL}$. Nilai RP kadar GDP terhadap kadar CRP sebesar 1,167 menunjukkan bahwa remaja obesitas dengan kadar GDP $>81,5$ $\mathrm{mg} / \mathrm{dL}$ dapat berisiko 1,1 kali untuk memiliki kadar CRP tinggi. Lebih dari 50\% remaja dengan kadar CRP tinggi memiliki kadar GDP $>81,5$ $\mathrm{mg} / \mathrm{dL}$.

\section{SIMPULAN}

Prevalensi sindrom metabolik pada remaja obesitas sebesar $15,2 \%$, yang ditemukan hanya pada remaja laki-laki. Frekuensi remaja perempuan dengan kadar $C$-reactive protein (CRP) tinggi lebih tinggi dibandingkan laki-laki. Besar risiko asupan gula sederhana yang tinggi, asupan serat yang rendah, dan kadar Glukosa Darah Puasa (GDP) $>81,5 \mathrm{mg} / \mathrm{dL}$ terhadap peningkatan kadar CRP pada remaja obesitas dengan sindrom metabolik berturut-turut adalah 2,1 kali; 3,7 kali; dan 1,1 kali.

\section{SARAN}

Untuk mencegah peningkatan kadar $C$ reactive protein (CRP) pada remaja obesitas dapat dilakukan dengan membatasi asupan makanan dan minuman yang mengandung gula sederhana menjadi $<10 \%$ total kebutuhan energi serta meningkatkan asupan serat sesuai kebutuhan terutama dari sayur dan buah.

\section{DAFTAR PUSTAKA}

1. Weiss R, Dziura J, Burgert TS, Tamborlane WV, Taksali SE, Yeckel CW, et al. Obesity and the Metabolic Syndrome in Children and Adolescents. The New England Journal of Medicine 2004; 350:2362-74.

2. Badan Litbang Kesehatan Departemen Kesehatan RI. Laporan Hasil Riset Kesehatan Dasar (Riskesdas) Nasional. Jakarta. 2013. 
3. Badan Litbang Kesehatan Departemen Kesehatan RI. Laporan Hasil Riset Kesehatan Dasar (Riskesdas) Nasional. Jakarta. 2010.

4. Mexitalia M, Utari A, Sakundarno M, Yamauchi T, Subagio HW, Soemantri A. Sindrom Metabolik pada Remaja Obesitas. Media Medika Indonesia 2009; 43(6).

5. Virgianto G. Konsumsi Fast Food sebagai Faktor Risiko terjadinya Obesitas pada Remaja Usia 1517 Tahun. Semarang: Universitas Diponegoro. 2006.

6. Srinivasan SR, Myers L, Berenson GS. Predictability of childhood adiposity and insulin for developing insulin resistance syndrome (syndrome X) in young adulthood. The Bogalusa Heart Study. Diabetes 2002; 51:204-209.

7. Niyomtham S, Ratchaneewan $M$, Chaiwat C, Jermsri P, Meemark S, Tangvarasittichai O, et al. Abdominal Obesity, Hypertension, Hyperglicemia, and Dyslipidemia in Rural Thai People. Asia Journal of Public Health 2011; 3(1):3-8.

8. Sattar N, McConnachie A, Shaper AG, Blauw GJ, Buckley BM, de Craen AJ, et al. Can metabolic syndrome usefully predict cardiovascular disease and diabetes? Outcome data from two prospective studies. Lancet 2008; 371:1927-1935.

9. Freeman DJ, Norrie J, Caslake MJ, et al. Creactive protein is an independent predictor of risk for the development of diabetes in the West of Scotland Coronary Prevention Study. Diabetes 2002; 51:1596-1600.

10. El-shorbagy HH, Ghoname IA. High-sensitivity C-reactive protein as a marker of cardiovascular risk in obese children and adolescents. Health 2010; 2(9):1078-1084.

11. Kosova EC, Auinger $\mathrm{P}$, Bremer AA. The relationships between sugar-sweetened beverage intake and cardiometabolic markers in young children. J Acad Nutri Dietetics 2013; 113:219227.

12. Aeberli I, Gerber PA, Hochuli M, Kohler S, Haile SR, Gouni-Berthold I, et al. Low to moderate sugar-sweetened beverage consumption impairs glucose and lipid metabolism and promotes inflammation in healthy young men: a randomized controlled trial. Am J Clin Nutr 2011; 94:479-485.

13. Sorensen L, Raben A, Stender S, Astrup A. Effect of sucrose on inflammatory markers in overweight humans. Am J Clin Nutr 2005; 82:421.

14. Sonestedt E, Overby NC, Laaksonen DE, Birgisdottir BE. Does high sugar consumption exacerbate cardiometabolic risk factors and increase the risk of type 2 diabetes and cardiovascular disease? Food Nutr Res 2012; 56.

15. Santos AC, Lopes C, Guimarães JT, Barros H. Central obesity as a major determinant of increased high-sensitivity C-reactive protein in metabolic syndrome. Int J Obes (Lond) 2005; 29:1452-1456.
16. Souto DL, Zajdenverg L, Rodacki M, Rosado EL. Does sucrose intake affect antropometric variables, glycemia, lipemia and C-reactive protein in subjects with type 1 diabetes?: a controlled-trial. Diabetology \& Metabolic Syndrome 2013; 5:67.

17. Esposito K, Marfella R, Ciotola M, et al. Effect of a Mediterranean-style diet on endothelial dysfunction and markers of vascular inflammation in the metabolic syndrome: a randomized trial. JAMA 2004; 292:1440-6.

18. Yunsheng Ma, Jennifer A Griffith, Lisa ChasanTaber, Barbara C Olendzki, Elizabeth Jackson, Edward J Stanek III, et al. Association between dietary fiber and serum C-reactive protein. Am J Clin Nutr 2006; 83(4):760-766.

19. Abdrabo AA. Association between fasting plasma glucose and highly sensitive C-reactive protein in a Sudanese population. Sudan Med J 2012; 48(2).

20. Sabanayagam C, Shankar A, Lim SC, Lee J, Tai ES, Wong TY. Serum C-reactive protein level and prediabetes in two Asian populations. Diabetologia 2011; 54:767-775.

21. Liu S, Manson JE, Buring JE, Stampfer MJ, Willett WC, Ridker PM. Relation between a diet with a high glycemic load and plasma concentrations of high-sensitivity C-reactive protein in middle-aged women. Am J Clin Nutr 2002;75:492-8.

22. Kawamoto R, Tabara Y, Kohara K, et al. Association between fasting plasma glucose and high-sensitivity C-reactive protein: gender differences in a Japanese community-dwelling population. Cardiovascular Diabetology 2011; 10:51.

23. Lorenzo C, Williams K, Hunt KJ, Haffner SM. The National Cholesterol Education ProgramAdult Treatment Panel III, International Diabetes Federation, and World Health Organization Definitions of the Metabolic Syndrome as Predictors of Incident Cardiovascular Disease and Diabetes. Diabetes Care 2007; 30:8-13.

24. Irz X, Shankar B, Srinivasan CS. Dietary Recommendations in the Report of a Joint WHO/FAO Expert Consultation on Diet, Nutrition and the Prevention of Chronic Diseases (WHO Technical Report Series 916, 2003): Potential Impact on Consumption, Production and Trade of Selected Food Products. 2003.

25. Bodhy W, Manampiring AE. Prevalensi Sindroma Metabolik pada Remaja di Kota Tomohon. Manado: Universitas Sam Ratulangi.2011.

26. Sibarani RP, Rudijanto A, Dekker J, Hiene RJ. The Petai China Study: Metabolic Syndrome Among Obese Indonesian Chinese Adolescents. The Indonesian Journal of Internal Medicine 2006; 38:142-144.

27. Sarrafzadegan N, Gharipour M, Sadeghi M, Nouri F, Asgary S, Zarfeshani S. Differences in the prevalence of metabolic syndrome in boys and 
girls based on various definitions.ARYA Atheroscler 2013; 9(1):70-6.

28. Mustofa S. Sindrom Metabolik dan Defisiensi Testosteron. Majalah Kesehatan PharmaMedika 2010; 2(2).

29. Park HS, Oh SW, Cho SI, Choi WH, Kim YS. The Metabolic Syndrome and Associated Lifestyle Factor among South Korean Adults. International Journal of Epidemiology 2004; 33: 328-36.

30. Rizzo ACB, Goldberg TBL, Silva CC, Kurokawa $\mathrm{CS}$, Corrente JE. Metabolic syndrome risk factors in overweight, obese, and extremely obese brazilian adolescents. Nutritional Journal 2013; 12:19.

31. Buse JB, Kenneth SP \& Charles FB. Type 2 Diabetes Mellitus. William Textbook of Endocrinology 2002; 1427-1451.

32. Mahan L, Khateleen S Escoott-stump. Krause's Food, Nutrition, and Diet Therapy, $13^{\text {th }}$ Edition. USA : Saunders. 2012.

33. Anderson, JW. Dietary fiber prevents carbohydrate-induced hypertriglyceridemia. Current Atherosclerosis Reports 2000; 2(6):536541.

34. Sareen SG, Jack LS, James LG. Advanced Nutrition and Human Metabolism. 5th edition. Canada: Wadsworth Cengage Learning. 2009.

35. Cruz LL, Cardoso LD, Pala D, Paula H, Lamounier JA, Silva CA, et al. Metabolic syndrome components can predict $\mathrm{C}$ reactive protein concentration in adolescent. Nutr Hosp 2013; 28(5):1580-1586.

36. Lau D, Yan H, Abdel-hafez M, Kermouni A. Adipokines and the paracrine control of their production in obesity and diabetes. Int $\mathbf{J}$ Obes Relat Metab Disord 2002; 26: S111.

37. DiMeglio DP, Mattes RD, Liquid versus solid carbohydrate: Effects on food intake and body weight. Int J Obes Relat Metab Disord 2000; 24(6):794-800.

38. Liu S, Manson JE, Buring JE, Stampfer MJ, Willett WC, Ridker PM. Relation between a diet with a high glycemic load and plasma concentrations of high-sensitivity C-reactive protein in middle-aged women. Am J Clin Nutr 2002; 75(3):492-498.

39. Ajani UA, Ford ES, Mokdad AH. Dietary fiber and $\mathrm{C}$-reactive protein: findings from national health and nutrition examination survey data. J Nutr 2004;134:1181-5. 